\title{
Aurones: A Promising Heterocyclic Scaffold for the Development of Potent Antileishmanial Agents
}

\author{
Marina Roussaki, ${ }^{1}$ Sofia Costa Lima, ${ }^{2}$ Anna-Maria Kypreou, ${ }^{1}$ Panagiotis Kefalas, ${ }^{3}$ \\ Anabela Cordeiro da Silva, ${ }^{2,4}$ and Anastasia Detsi ${ }^{1}$ \\ ${ }^{1}$ Laboratory of Organic Chemistry, School of Chemical Engineering, National Technical University of Athens, \\ Heroon Polytechniou 9, Zografou Campus, 15780 Athens, Greece \\ ${ }^{2}$ Parasite Disease Group, IBMC-Institute for Molecular and Cell Biology, University of Porto, Rua do Campo Alegre, \\ 823, 4150-180 Porto, Portugal \\ ${ }^{3}$ Department of Food Quality and Chemistry of Natural Products, Mediterranean Agronomic Institute of Chania, \\ International Centre for Advanced Mediterranean Agronomic Studies, 73100 Chania, Crete, Greece \\ ${ }^{4}$ Department of Biological Sciences, Faculty of Pharmacy, University of Porto, Rua de Jorge Viterbo Ferreiera, \\ 228, 4050-313 Porto, Portugal \\ Correspondence should be addressed to Anastasia Detsi, adetsi@chemeng.ntua.gr
}

Received 27 May 2012; Accepted 31 July 2012

Academic Editor: O. Bruno

Copyright ( $\odot 2012$ Marina Roussaki et al. This is an open access article distributed under the Creative Commons Attribution License, which permits unrestricted use, distribution, and reproduction in any medium, provided the original work is properly cited.

A series of ( $\mathrm{Z}$ )-2-benzylidenebenzofuran-3-(2H)-ones (aurones) bearing a variety of substituents on rings $\mathrm{A}$ and $\mathrm{B}$ were synthesized and evaluated for their antiparasitic activity against the intracellular amastigote form of Leishmania infantum and their cytotoxicity against human THP1-differentiated macrophages. In general, aurones bearing no substituents on ring A (compounds 4a-4f) exhibit higher toxicity than aurones with 4,6-dimethoxy substitution (compounds $\mathbf{4 g}-\mathbf{4 l}$ ). Among the latter, two aurones possessing a $2^{\prime}$-methoxy or a $2^{\prime}$-methyl group (compounds $4 \mathbf{i}$ and $\mathbf{4 j}$ ) exhibit potent antileishmanial activity $\left(\mathrm{IC}_{50}=1.3 \pm 0.1 \mu \mathrm{M}\right.$ and $\mathrm{IC}_{50}=1.6 \pm 0.2 \mu \mathrm{M}$, resp.), comparable to the activity of the reference drug Amphotericin $\mathrm{B}$, whereas they present significantly lower cytotoxicity than Amphotericin B as deduced by the higher selectivity index.

\section{Introduction}

Leishmaniasis, an infectious disease caused by protozoan parasites belonging to the genus Leishmania $(L$.), is transmitted to humans through the bite of female phlebotomine sand flies infected with the parasite. This disease is manifested in three forms: cutaneous leishmaniasis $(\mathrm{CL})$, which is the most common form, mucocutaneous leishmaniasis (MCL), and visceral leishmaniasis (VL) [1]. CL causes ulcers on the exposed parts of the human body which leave permanent scars when healed, whereas MCL causes the destruction of the mucous membranes of the nose, mouth, and throat cavities and surrounding tissues leading to serious disabling of the patient. Although they do not cause death of the patient, these two forms pose a serious social problem as a result of prejudice or even rejection of the disfigured patient from the community. VL is the most serious form of the disease which inevitably leads to death if left untreated [2]. Leishmaniasis is distributed in four continents and affects millions of people, especially in the poor developing countries where the lack of efficient medical care and resources, malnutrition, and weak immune system enhance the possibility of infection [3]. Moreover, co-infection with HIV is an emerging threat as the immunosuppressed HIV patients are especially vulnerable to VL infection. In fact, the majority of the VL cases reported in southern Europe involves HIV-infected patients [4]. In addition, in developed countries, where leishmaniasis is not endemic, the cases of infected population have increased over the last decade, in association with increasing international tourism, military operations, and the influx of immigrants from endemic countries [5]. 
Treatment of leishmaniasis lies exclusively on chemotherapy because no human vaccine is yet available [6]. The first-line drugs are the pentavalent antimonials meglumine antimoniate (Glucantime) and sodium stibogluconate (Pentostam), which are now obsolete in India due to resistance development although they are still used in other countries $[2,7]$. As second-line treatment, liposomal formulations of the polyene antibiotic Amphotericin B have been developed in order to increase efficacy and reduce toxicity of the drug [8]. However, although it has high cure rates, this drug suffers from severe side-effects and high cost which renders its use unaffordable for patients in developing countries. New, cheaper formulations of Amphotericin B are currently being explored as alternatives [9]. The first oral treatment for leishmaniasis has been developed in 2002 using miltefosine, an alkylphospholipid initially used as an anticancer agent [10]. Unfortunately, miltefosine has exhibited teratogenic potential; therefore its use is prohibited in pregnant women [11]. Current advances in leishmaniasis chemotherapy include paromomycin, an aminoglycoside antibiotic, which has recently started to be used as a treatment for CL and VL and sitamaquine, a 8-aminoquinolone that has reached phase II clinical trials for the treatment of VL $[10,12,13]$.

The development of new, more effective, less toxic, and affordable antileishmanial drugs is still a major goal in medicinal chemistry based not only on rational drug design $[14,15]$, but also on the exploitation of nature either as a source of phytochemical antiparasitics or as an inspiration for new molecular scaffolds [16-19]. The evaluation of the antiparasitic activity of plant extracts or isolated natural products constitutes an attractive approach for the development of new efficient drugs.

Aurones, $(Z)$-2-benzylidenebenzofuran-3-(2H)-ones (Figure 1), constitute a subclass of flavonoids which occur rarely in nature. They are responsible for the bright yellow color of some popular ornamental flowers and are biosynthesized from chalcones by the key enzyme aureusidin synthase. Although the studies of the biological activities of aurones are still limited, these natural products and their synthetic analogues have proved to be promising bioactive compounds with a broad spectrum of activity including anticancer [20-22] antimicrobial, [23] and antioxidant [24, $25]$ properties whereas they possess enzyme inhibitory [25, 26], or enzyme-inducing activity [27].

The antileishmanial activity of a series of aurones was first reported by Kayser and Kiderlen in 1999 [28]. In this study, five aurones and one aurone glucoside were tested against extracellular promastigotes of L. donovani, L. infantum, L. enriettii, and L. major, and against intracellular amastigote $L$. donovani, and the results revealed that the compounds were active against the parasites in concentrations ranging between 0.4 and $5.0 \mu \mathrm{g} / \mathrm{mL}$ while they showed moderate cytotoxicity. The same research group studied structurally diverse aurones and auronols for their inhibitory activity against the mitochondrial NADHfumarate reductase of $L$. major promastigotes. The majority

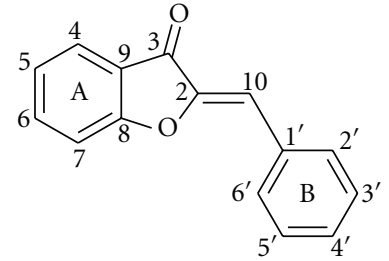

FIGURE 1: Chemical structure and numbering of the aurone scaffold.

of the compounds were potent inhibitors of the enzyme in a dose- and structure-dependent manner [29].

As a continuation of our studies towards the synthesis and activity evaluation of novel bioactive natural product analogues, we have focused on the aurone scaffold in order to further explore its potential in the development of novel and efficient antileishmanial agents. In this work we describe the synthesis and structural characterization of aurone derivatives bearing various substituents on different positions of rings $\mathrm{A}$ and $\mathrm{B}$ as well as the evaluation of their activity against the intracellular form of $L$. infantum parasites.

\section{Results and Discussion}

2.1. Chemistry. Aurones $\mathbf{4 a}-\mathbf{4 l}$ have been synthesized via the oxidative cyclization of the corresponding chalcones using mercury(II) acetate in pyridine. The synthesis and characterization of compounds $\mathbf{4 a - 4 i}$ has been described in detail in one of our previous publications [25]. In order to accomplish the synthesis of aurones $\mathbf{4 j - 4}$, chalcones $\mathbf{3} \mathbf{j}-$ 31 were synthesized via the Claisen-Schmidt condensation reaction between $4^{\prime}, 6^{\prime}$-dimethoxy-2' -hydroxy-acetophenone (1b) and the appropriately substituted benzaldehyde in basic conditions (20\% aqueous $\mathrm{KOH}$ in ethanol) (Scheme 1 ).

The oxidative cyclization of chalcones $\mathbf{3} \mathbf{j}-\mathbf{3 l}$ proceeds smoothly by refluxing the corresponding chalcone with $\mathrm{Hg}(\mathrm{OAc})_{2}$ in pyridine for $1 \mathrm{~h}$ (Scheme 1$)$. The desired aurones $\mathbf{4} \mathbf{j}-\mathbf{4 l}$ were isolated as yellow solids after acidification with aqueous $\mathrm{HCl} 10 \%$, extraction with an appropriate solvent, and purification.

The structural characterization of the synthesized compounds was achieved using ${ }^{1} \mathrm{H}$ and ${ }^{13} \mathrm{C}$ NMR spectroscopy as well as MS/ESI(+) spectroscopy. The ${ }^{1} \mathrm{H}$ NMR spectra of chalcones $\mathbf{3} \mathbf{j}-\mathbf{3 l}$ are characterized by a signal at a low field $(\sim 14 \mathrm{ppm})$ attributed to the proton of the $2^{\prime}-\mathrm{OH}$ group which is deshielded as a result of taking part in a strong intramolecular hydrogen bond with the neighbouring carbonyl group, and the pair of $\mathrm{AB}$ doublets owed to the vinylic protons, with $J \sim 15 \mathrm{~Hz}$ confirming the E-geometry of the double bond. In the case of chalcones $3 \mathbf{j}$ and $3 \mathbf{k}$, the presence of a substituent on position 2 results in a significant downfield shift of the $\mathrm{AB}$ doublets (8.08 and $8.13 \mathrm{ppm}$ for $\mathrm{H}_{\beta}$ and 7.81 and $7.87 \mathrm{ppm}$ for $\mathrm{H}_{\alpha}$, resp.) as compared to the corresponding chemical shifts in the ${ }^{1} \mathrm{H}$ NMR spectrum of the naturally occurring chalcone 

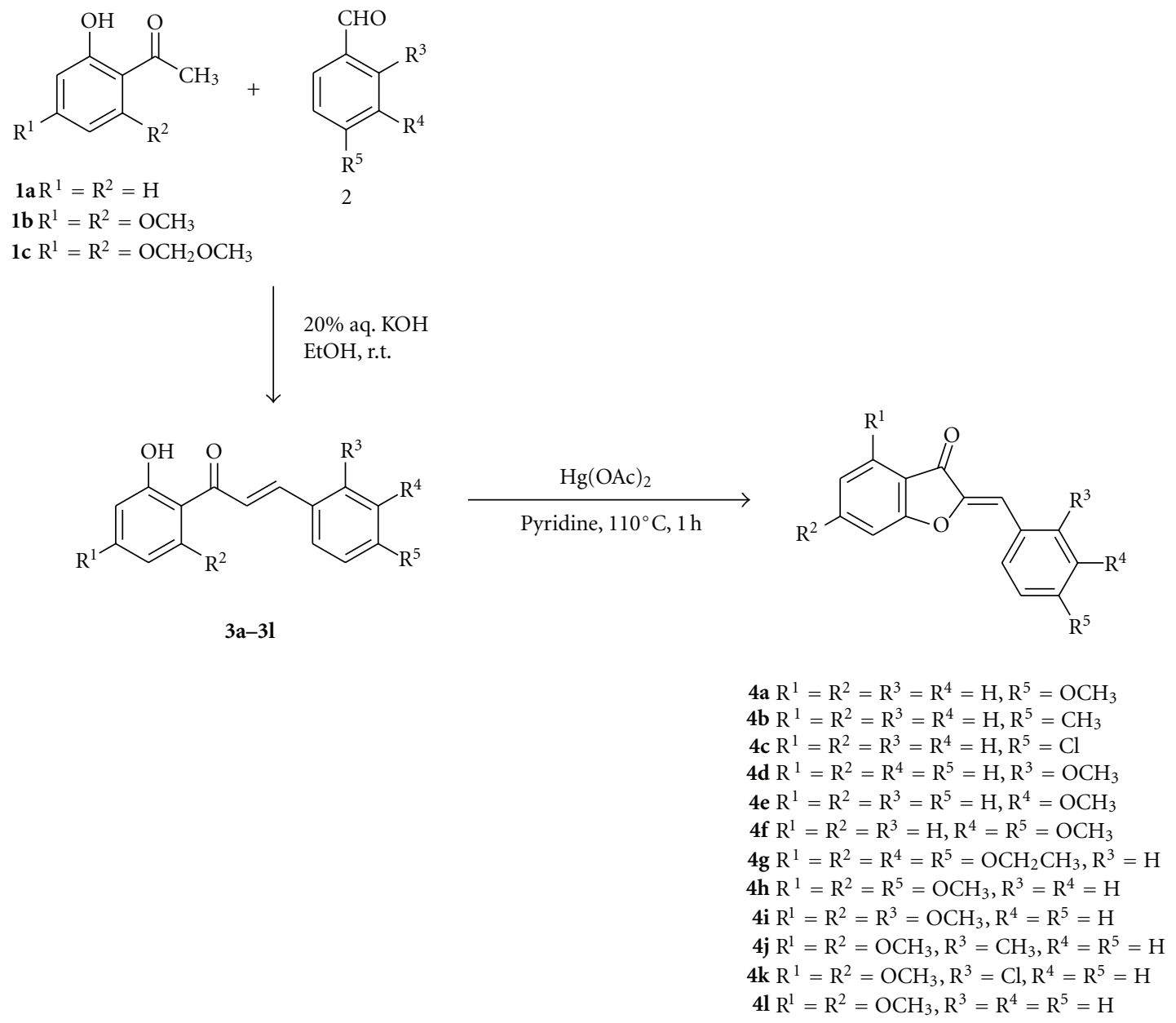

Scheme 1: Synthesis of chalcones $\mathbf{3 a}-\mathbf{3 l}$ and of the corresponding aurones $\mathbf{4 a}-\mathbf{4 l}$.<smiles>[R3]c1ccccc1/C=C/C(=O)c1c(O)cc(OC)cc1OC</smiles>

Scheme 2: Major fragmentation pathway of chalcones $\mathbf{3} \mathbf{j}-\mathbf{3 l}$ in CID ESI-MS.

flavokawain B (31) (7.91 ppm for $\mathrm{H}_{\beta}$ and $7.79 \mathrm{ppm}$ for $\mathrm{H}_{\alpha}$ ). This difference should be attributed to the "ortho" effect, a phenomenon which renders the spectra of ortho-substituted aromatic compounds more complex than those of their meta- and para-substituted counterparts [30].

The mass spectra of chalcones $\mathbf{3} \mathbf{j}-\mathbf{3 l}$ were obtained using the electrospray ionisation (ESI) technique and an ion trap detector. In the conditions of the ESI experiment, chalcones are protonated and the $[\mathrm{M}+\mathrm{H}]^{+}$ion is detected instead of the molecular ion. In the collision-induced dissociation (CID) mass spectra of the $[\mathrm{M}+\mathrm{H}]^{+}$cations of $3 \mathbf{j}-3 \mathbf{l}$, the fragmentation pattern observed involved a scission of the bond between the carbonyl carbon and the vinylic $\mathrm{C}_{\alpha}$, which produced Fragment $\mathrm{A}$ as the basic ion (Scheme 2).

In general, the ${ }^{1} \mathrm{H}$ NMR spectra of aurones are characterized by the presence of a singlet owed to the exocyclic vinylic proton, the chemical shift of which is indicative of the geometrical configuration of the molecule and is affected significantly by the position of the substituents on ring B and, to a lesser extent, by the presence of alkoxy substituents on ring $\mathrm{A}$. In the case of the synthesized aurones $\mathbf{4 a}-\mathbf{4} \mathbf{c}$ and $4 \mathrm{e}-4 \mathrm{~h}, 4 \mathrm{l}$, this singlet appears in the range of $6.57-6.89 \mathrm{ppm}$ [25], in accordance with the previous findings by us and other research groups $[21,24,25]$. The chemical shift of 
TABLE 1: Energy calculation of selected energetically minimized aurones $\left(\mathrm{kJ} \mathrm{mol}^{-1}\right)$.

\begin{tabular}{lcc}
\hline Compound & Potential energy & Torsional energy \\
\hline $\mathbf{4 a}(Z$-isomer $)$ & 88.08 & -1.82 \\
$\mathbf{4 a}(E$-isomer $)$ & 110.16 & 12.14 \\
$\mathbf{4 d}(Z$-isomer $)$ & 107.57 & 13.54 \\
$\mathbf{4 d}(E$-isomer $)$ & 117.81 & 13.18 \\
$\mathbf{4 h}(Z$-isomer $)$ & 139.95 & 22.83 \\
$\mathbf{4 h}(E$-isomer $)$ & 162.43 & 37.43 \\
$\mathbf{4 i}(Z$-isomer $)$ & 132.81 & 0.76 \\
$\mathbf{4 i}(E$-isomer $)$ & 169.79 & 38.41 \\
\hline
\end{tabular}

the vinylic proton in the case of aurones $4 \mathbf{d}, 4 \mathbf{i}-\mathbf{4 k}$ which bear a substituent on position $2^{\prime}$ is observed downfield, at $7.00-7.49 \mathrm{ppm}$. Although some controversy was at first aroused as to if the downfield shift of vinylic $\mathrm{H}$ indicates the presence of the E-geometrical isomer of $2^{\prime}$-substituted aurones, the X-ray crystallographic analyses of two aurones reported recently proved that it is undoubtedly that the thermodynamically more stable $Z$-isomer always prevails $[21,31]$. As a result, the difference in chemical shifts is attributed to the ortho-effect.

The observation of only one signal owed to the vinylic proton indicates that the oxidative cyclization procedure applied leads exclusively to the formation of a single geometrical isomer, in this case the thermodynamically more stable $Z$-aurone [24]. In order to further support this hypothesis, in silico approaches were employed to perform energy calculations for selected aurones (4a, $4 \mathbf{d}, 4 \mathrm{~h}$, and $4 \mathbf{i})$. Results indicate that the $Z$ isomers exhibit lower potential energy thus higher stability than their $E$ counterparts. Differences in energy values between $E / Z$ isomers are mainly attributed to torsional energy contribution (Table 1).

2.2. Biological Assays. All compounds were tested in vitro with human THP1-differentiated macrophages and cell viability evaluated by MTT assay (Table 1). The ability to inhibit the growth of the parasite without affecting macrophage viability is a good indication of selectivity of the compound, a desirable property for a drug candidate. The less cytotoxic aurones on the mammalian cells $\left(\mathrm{IC}_{50}>20 \mu \mathrm{M}\right)$ were then assessed against the intracellular amastigote stage of $L$. infantum. The selectivity index (SI) was determined based on ratio of $\mathrm{IC}_{50}$ values measured on the mammalian cells and for the intracellular parasite $\left(\mathrm{IC}_{50}\right.$ for mammalian cell line/ $\mathrm{IC}_{50}$ for parasite). This ratio provides an indication of the selectivity of these compounds against L. infantum amastigotes when compared to normal cells. The results are shown in Table 2.

Aurones $\mathbf{4 a}-\mathbf{4 f}$ bearing no substituents on ring A generally exhibited higher toxicity against THP1 cells than aurones 4g-4l which possess oxygenated substituents on the same ring. Among the nonsubstituted on ring A compounds, aurone $4 \mathrm{e}$ did not show significant toxicity but it is not a very active antileishmanial agent either $\left(\mathrm{IC}_{50}=4.7 \pm 0.5 \mu \mathrm{M}\right)$. The compounds possessing oxygenated substituents on positions
4 and 6 of ring A generally were less toxic against THP1 cells. However, aurone $\mathbf{4 g}$, one of the least toxic compound of the series, which possesses four methoxymethyl (MOM) groups, is a weak antiparasitic agent $\left(\mathrm{IC}_{50}=5.1 \pm 0.3 \mu \mathrm{M}\right)$.

The position and electronic nature of the substituent on ring $B$ seem to significantly affect the activity of the compounds against $L$. infantum parasite as well as their cytotoxicity: the most active and one of the less toxic compounds of the series, 2',4,6-trimethoxyaurone $4 \mathbf{i}$ bears a methoxy group on position $2^{\prime}$ of ring $B$ and exhibits potent antileishmanial activity with $\mathrm{IC}_{50}=1.3 \pm 0.1 \mu \mathrm{M}$. Changing the electron-donating methoxy group to the nonoxygenated electron-donating methyl group on the same position results in compound $\mathbf{4 j}$, which exhibits comparable antileishmanial activity $\left(\mathrm{IC}_{50}=1.6 \pm 0.2 \mu \mathrm{M}\right)$, with $4 \mathbf{i}$ but slightly higher toxicity. On the other hand, when position $2^{\prime}$ of ring $\mathrm{B}$ is occupied by an electron-withdrawing chlorine atom as in aurone $4 \mathbf{k}$, antiparasitic activity is substantially lower $\left(\mathrm{IC}_{50}=12.2 \pm 1.4 \mu \mathrm{M}\right)$ whereas the compound is not toxic to mammalian cells (in fact aurone $4 \mathbf{k}$ is the least toxic compound of the series studied in this work). Aurone $4 \mathbf{l}$ in which ring B is unsubstituted possesses significant antileishmanial activity $\left(\mathrm{IC}_{50}=2.1 \pm 0.9 \mu \mathrm{M}\right)$ although lower than the $2^{\prime}$-substituted analogues $4 \mathbf{i}$ and $\mathbf{4 j}$.

Compounds $\mathbf{4} \mathbf{i}$ and $\mathbf{4 j}$ exhibited higher selectivity towards the intracellular form of the L. infantum parasite, when compared to the toxicity exerted on the mammalian cells ( $\mathrm{SI}=57.5$ and 43.4, resp.). Amphotericin $\mathrm{B}$ was used as a reference antileishmanial drug currently applied on the chemotherapy of leishmaniasis. Its activity on the intracellular amastigotes was very similar with the one obtained with compounds $\mathbf{4 i}$ and $\mathbf{4 j}$, although Amphotericin $\mathrm{B}$ was more toxic on the human-differentiated macrophages $(\mathrm{SI}=20.6)$.

\section{Experimental}

${ }^{1} \mathrm{H}$ NMR spectra and ${ }^{13} \mathrm{C}$ NMR spectra were recorded on a Varian Gemini $2000300 \mathrm{MHz}$ spectrometer or a Varian $600 \mathrm{MHz}$ spectrometer. Coupling constants (J) are expressed in hertz $(\mathrm{Hz})$. Chemical shifts $(\delta)$ of NMR are reported in parts per million ( $\mathrm{ppm}$ ) units relative to the solvent. Melting points were determined on a Gallenkamp MFB-595 melting point apparatus and are uncorrected.

The LC/MS analysis was performed using Varian LC/MS using the ElectroSpray Ionisation technique and an Ion Trap detector.

3.1. General Procedure for the Synthesis of Chalcones 3j-31. To a stirred solution of 2-hydroxy-4,6-dimethoxy-acetophenone (1b) (1eq) and a substituted benzaldehyde (1eq) in ethanol was added $\mathrm{KOH}$ (3eq, 20\% w/v aqueous solution) and the mixture was stirred at room temperature for 24$72 \mathrm{~h}$. The reaction mixture was cooled to $0^{\circ} \mathrm{C}$ (ice-water bath) and acidified with $\mathrm{HCl}$ (10\% v/v aqueous solution). The precipitate formed was filtered and washed with $10 \%$ aqueous $\mathrm{HCl}$ solution. 
TABLe 2: Antileishmanial activity and cytotoxicity of the synthesized aurones.

\begin{tabular}{|c|c|c|c|}
\hline \multirow{2}{*}{ Compound } & \multicolumn{2}{|c|}{$\mathrm{IC}_{50}(\mu \mathrm{M})$} & \multirow{2}{*}{ Selectivity index $(\mathrm{SI})^{\mathrm{a}}$} \\
\hline & L. infantum intracellular amastigotes & THP1-differentiated macrophages & \\
\hline $4 a$ & $\mathrm{nd}^{\mathrm{b}}$ & $16.5 \pm 3.1$ & nd \\
\hline $4 b$ & nd & $8.5 \pm 0.8$ & nd \\
\hline $4 c$ & nd & $14.5 \pm 2.1$ & nd \\
\hline $4 d$ & nd & $17.5 \pm 3.1$ & nd \\
\hline $4 e$ & $4.7 \pm 0.5$ & $54.2 \pm 7.3$ & 11.5 \\
\hline $4 \mathrm{f}$ & nd & $20.5 \pm 1.2$ & nd \\
\hline $4 \mathrm{~g}$ & $5.1 \pm 0.3$ & $62.5 \pm 1.3$ & 12.4 \\
\hline $4 \mathrm{~h}$ & nd & $19.6 \pm 2.5$ & nd \\
\hline $4 \mathbf{i}$ & $1.3 \pm 0.1$ & $75.4 \pm 4.7$ & 57.5 \\
\hline $4 \mathbf{j}$ & $1.6 \pm 0.2$ & $68.1 \pm 2.1$ & 43.4 \\
\hline $4 \mathrm{k}$ & $12.2 \pm 1.4$ & $>100$ & $>8.2$ \\
\hline 41 & $2.1 \pm 0.9$ & $57.5 \pm 3.4$ & 26.9 \\
\hline Amphotericin B & $1.2 \pm 0.1$ & $23.8 \pm 2.3$ & 20.6 \\
\hline
\end{tabular}

${ }^{a}$ The selectivity index represents the ratio of $\mathrm{IC}_{50}$ on THP1-differentiated macrophages to the $\mathrm{IC}_{50}$ on intracellular parasite.

${ }^{\mathrm{b}} \mathrm{nd}$ : not determined, for compounds with $\mathrm{IC}_{50}$ values below $20 \mu \mathrm{M}$ on THP1-differentiated macrophages.

2'-Hydroxy-4',6'-dimethoxy-2-methyl-chalcone (3j) [32]. Prepared following the general procedure starting from 2-hydroxy-4,6-dimethoxy-acetophenone (1b, $500 \mathrm{mg}$, $2.3 \mathrm{mmol}$ ) and o-methylbenzaldehyde (278 $\mathrm{mg}, 2.3 \mathrm{mmol}$ ), dissolved in $9 \mathrm{~mL}$ ethanol and $\mathrm{KOH}$ ( $20 \%$ aqueous solution, $2 \mathrm{~mL}$ ). The solid was recrystallized from methanol to afford yellow crystals. Yield: $420 \mathrm{mg}(61 \%)$. mp $117-$ $120^{\circ} \mathrm{C} ;{ }^{1} \mathrm{H}$ NMR $\left(\mathrm{CDCl}_{3}, 300 \mathrm{MHz}\right) \delta: 14.26(\mathrm{~s}, 1 \mathrm{H})$, $8.08(\mathrm{~d}, J=15.3 \mathrm{~Hz}, 1 \mathrm{H}), 7.81(\mathrm{~d}, J=15.9 \mathrm{~Hz}, 1 \mathrm{H})$, $7.64(\mathrm{~d}, J=6.6 \mathrm{~Hz}, 1 \mathrm{H}), 7.32-7.19(\mathrm{~m}, 3 \mathrm{H}), 6.13(\mathrm{~s}, 1 \mathrm{H})$, $5.98(\mathrm{~s}, 1 \mathrm{H}), 3.93(\mathrm{~s}, 3 \mathrm{H}), \quad 3.87(\mathrm{~s}, 3 \mathrm{H}), 2.52(\mathrm{~s}, 3 \mathrm{H}) .{ }^{13} \mathrm{C}$ NMR $\left(\mathrm{CDCl}_{3}, 75 \mathrm{MHz}\right) \delta \mathrm{ppm} 192.87,168.54,166.37$, $162.65,140.12,138.33,134.65,131.01,129.94,128.73$, $126.74,126.40,106.48,93.90,91.39,55.99,55.74,20.12$. MS (ESI) $\mathrm{m} / z[\mathrm{M}+1]^{+} 299$.

$2^{\prime}$-Hydroxy-4', $6^{\prime}$-dimethoxy-2-chloro-chalcone (3k). Prepared following the general procedure starting from 2-hydroxy-4,6-dimethoxy-acetophenone (1b, $500 \mathrm{mg}$, $2.3 \mathrm{mmol}$ ) and o-chlorobenzaldehyde $(328 \mathrm{mg}, 2.3 \mathrm{mmol}$ ), dissolved in $9 \mathrm{~mL}$ ethanol and $\mathrm{KOH}(20 \%$ aqueous solution, $2 \mathrm{~mL}$ ). The solid was recrystallized from methanol to afford yellow crystals. Yield: $518 \mathrm{mg}(70 \%) . \mathrm{mp} 135-136^{\circ} \mathrm{C}$ (lit. [33] mp $\left.136-137^{\circ} \mathrm{C}\right) ;{ }^{1} \mathrm{H}$ NMR $\left(\mathrm{CDCl}_{3}, 600 \mathrm{MHz}\right) \delta: 14.19$ $(\mathrm{s}, 1 \mathrm{H}), 8.13(\mathrm{~d}, J=15.6 \mathrm{~Hz}, 1 \mathrm{H}), 7.87(\mathrm{~d}, J=15.6 \mathrm{~Hz}, 1 \mathrm{H})$, 7.69-7.67 (m, $1 \mathrm{H}), \quad 7.43-7.42 \quad(\mathrm{~m}, 1 \mathrm{H}), \quad 7.31-7.28 \quad(\mathrm{~m}$, $2 \mathrm{H}), 6.11(\mathrm{~d}, J=1.8 \mathrm{~Hz}, 1 \mathrm{H}), 5.95(\mathrm{~d}, J=2.4 \mathrm{~Hz}, 1 \mathrm{H})$, $3.89\left(\mathrm{~s}, 3 \mathrm{H}, \mathrm{OCH}_{3}\right), \quad 3.83\left(\mathrm{~s}, 3 \mathrm{H}, \mathrm{OCH}_{3}\right) . \quad{ }^{13} \mathrm{C} \quad \mathrm{NMR}$ $\left(\mathrm{CDCl}_{3}, 75 \mathrm{MHz}\right) \delta: 192.48,168.62,166.55,162.62,138.03$, $135.53,133.98,130.83,130.41,130.18,127.95,127.12$, 106.45, 93.94, 91.45, 56.03, 55.78. MS (ESI) $\mathrm{m} / z[\mathrm{M}+1]^{+}$ 319.

$2^{\prime}$-Hydroxy-4', $6^{\prime}$-dimethoxy-chalcone (Flavokawain B, 3l). Prepared following the general procedure starting from 2-hydroxy-4,6-dimethoxy-acetophenone

(1b, $\quad 500 \mathrm{mg}$,
$2.3 \mathrm{mmol}$ ) and benzaldehyde ( $247 \mathrm{mg}, 2.3 \mathrm{mmol})$, dissolved in $9 \mathrm{~mL}$ ethanol and $\mathrm{KOH}$ (20\% aqueous solution, $2 \mathrm{~mL}$ ). The solid was recrystallized from methanol to afford orange crystals. Yield: $460 \mathrm{mg}(72 \%) . \mathrm{mp} 74-76^{\circ} \mathrm{C}$ (lit. [34] $\left.\mathrm{mp} 89-90^{\circ} \mathrm{C}\right) ;{ }^{1} \mathrm{H} \mathrm{NMR}\left(\mathrm{CDCl}_{3}, 600 \mathrm{MHz}\right): \delta 14.27$ (s, $\left.1 \mathrm{H}\right)$, $7.91(\mathrm{~d}, J=15.6 \mathrm{~Hz}, 1 \mathrm{H}), 7.79(\mathrm{~d}, J=15.6 \mathrm{~Hz}, 1 \mathrm{H}), 7.61$ $(\mathrm{dd}, J=7.8 \mathrm{~Hz}, J=1.2 \mathrm{~Hz}, 2 \mathrm{H}), 7.42-7.39(\mathrm{~m}, 3 \mathrm{H}), 6.10$ $(\mathrm{d}, J=2.4 \mathrm{~Hz}, 1 \mathrm{H}),, 5.96(\mathrm{~d}, J=2.4 \mathrm{~Hz}, 1 \mathrm{H}), 3.90(\mathrm{~s}, 3 \mathrm{H})$, $3.84(\mathrm{~s}, 3 \mathrm{H}) .{ }^{13} \mathrm{C}$ NMR $\left(\mathrm{CDCl}_{3}, 75 \mathrm{MHz}\right) \delta: 192.77,168.54$, $166.37,162.63,142.46,135.68,130.20,129.01,128.50$, $127.65,106.45,93.90,91.40,55.99,55.73$. MS (ESI) $\mathrm{m} / \mathrm{z}$ $[\mathrm{M}+1]^{+} 285$.

3.2. General Procedure for the Preparation of Z-Aurones $\mathbf{4 j - 4} \boldsymbol{k}$. To a solution of mercuric acetate (1.2eq) in pyridine was added chalcone (1eq) at room temperature and the mixture was stirred at $110^{\circ} \mathrm{C}$ for $1 \mathrm{~h}$. The cooled reaction mixture was poured into ice cold water and acidified with $\mathrm{HCl}(10 \%$ aqueous solution). The precipitated solid was extracted with dichloromethane, the extracts were dried $\left(\mathrm{Na}_{2} \mathrm{SO}_{4}\right)$ and the solvent was evaporated to give a solid which was further purified by recrystallization from methanol/hexane.

4, 6-Dimethoxy-2'-methylaurone (4j). Prepared following the general procedure starting from chalcone $3 \mathbf{j}$ ( $200 \mathrm{mg}$, $0.67 \mathrm{mmol}$ ) in $7 \mathrm{~mL}$ pyridine. After recrystallization, the product was obtained as yellow crystals. Yield: $112 \mathrm{mg}$ (48\%). mp $180-183^{\circ} \mathrm{C}$ (lit. [21] mp $194-195^{\circ} \mathrm{C}$ ); ${ }^{1} \mathrm{H}$ $\operatorname{NMR}\left(\mathrm{CDCl}_{3}, 300 \mathrm{MHz}\right) \delta: \quad 8.15(\mathrm{~d}, J=6 \mathrm{~Hz}, 1 \mathrm{H})$, 7.32-7.23 (m, 4H, ), $7.00(\mathrm{~s}, 1 \mathrm{H}), 6.39(\mathrm{~d}, J=1.8 \mathrm{~Hz}, 1 \mathrm{H})$, $6.15(\mathrm{~d}, J=1.8 \mathrm{~Hz}, 1 \mathrm{H}), 3.98(\mathrm{~s}, 3 \mathrm{H}), 3.93(\mathrm{~s}, 3 \mathrm{H}), 2.52$ $(\mathrm{s}, 3 \mathrm{H}) .{ }^{13} \mathrm{C} \quad \mathrm{NMR} \quad\left(\mathrm{CDCl}_{3}, 75 \mathrm{MHz}\right) \delta: \quad 180.86,169.30$, $169.09,159.57,148.14,138.96,131.21,130.90,130.74$, $129.42,126.35,124.73,107.95,105.41,94.17,89.33,56.37$, $56.28,20.48$. 
4, 6-Dimethoxy-2'-chloro-aurone (4k). Prepared following the general procedure starting from chalcone $3 \mathbf{k}(250 \mathrm{mg}$, $0.78 \mathrm{mmol}$ ) in $7.3 \mathrm{~mL}$ pyridine. After recrystallization, the product was obtained as yellow crystals. Yield: $194 \mathrm{mg}(78 \%)$. mp 191-193 ${ }^{\circ} \mathrm{C}$ (lit. [27] mp 201-203 $\left.{ }^{\circ} \mathrm{C}\right) ;{ }^{1} \mathrm{H}$ NMR $\left(\mathrm{CDCl}_{3}\right.$, $300 \mathrm{MHz}) \delta: 8.26(\mathrm{dd}, J=7.5 \mathrm{~Hz}, J=1.8 \mathrm{~Hz}, 1 \mathrm{H}), 7.45$ $(\mathrm{dd}, J=7.8 \mathrm{~Hz}, J=1.5 \mathrm{~Hz}, 1 \mathrm{H}), 7.38-7.28(\mathrm{~m}, 2 \mathrm{H}), 7.22$ $(\mathrm{s}, 1 \mathrm{H}), 6.39(\mathrm{~d}, J=1.8 \mathrm{~Hz}, 1 \mathrm{H}), 6.16(\mathrm{~d}, J=1.8 \mathrm{~Hz}, 1 \mathrm{H})$, $3.98(\mathrm{~s}, 3 \mathrm{H}), \quad 3.93(\mathrm{~s}, 3 \mathrm{H}),{ }^{13} \mathrm{C} \mathrm{NMR}\left(\mathrm{CDCl}_{3}, 75 \mathrm{MHz}\right)$ $\delta: 180.47,169.28,169.22,159.74,148.90,135.70,132.02$, $130.87,130.19,130.08,127.02,106.07,105.26,94.33,89.50$, 56.41, 56.29. MS (ESI) $\mathrm{m} / \mathrm{z}[\mathrm{M}+1]^{+} 317$.

4, 6-Dimethoxyaurone (4l). Prepared following the general procedure starting from chalcone 31 ( $200 \mathrm{mg}, 0.70 \mathrm{mmol}$ ) in $6.6 \mathrm{~mL}$ pyridine. After recrystallization, the product was obtained as yellow crystals. Yield: $88 \mathrm{mg}(44 \%) . \mathrm{mp}$ 139-142 ${ }^{\circ} \mathrm{C}$ (lit. [34] mp $\left.152-153^{\circ} \mathrm{C}\right) ;{ }^{1} \mathrm{H}$ NMR $\left(\mathrm{CDCl}_{3}\right.$, $300 \mathrm{MHz}) \delta: 7.87(\mathrm{~d}, J=7.6 \mathrm{~Hz}, 2 \mathrm{H}), 7.46-7.36(\mathrm{~m}, 3 \mathrm{H})$, $6.78(\mathrm{~s}, 1 \mathrm{H}), 6.40(\mathrm{~d}, J=1.8 \mathrm{~Hz}, 1 \mathrm{H}), 6.15(\mathrm{~d}, J=$ $1.8 \mathrm{~Hz}, 1 \mathrm{H}), 3.98(\mathrm{~s}, 3 \mathrm{H}), 3.94(\mathrm{~s}, 3 \mathrm{H}) ;{ }^{13} \mathrm{C} \mathrm{NMR}\left(\mathrm{CDCl}_{3}\right.$, $75 \mathrm{MHz}) \delta: 180.85,169.25,169.16,159.60,148.03,132.74$, $131.25,131.15,129.46,128.92,110.93,105.40,94.22,89.41$, 56.38, 56.26. MS (ESI) $m / z[\mathrm{M}+1]^{+} 283$.

\subsection{Parasite and Cell Cultures}

3.3.1. Parasites. A cloned line of L. infantum (MOM/ MA671 TMAP263) promastigotes, stably expressing the luciferase gene (LUC), was grown in RPMI 1640 medium (Bio Whitaker, Belgium) supplemented with 10\% heatinactivated fetal bovine serum (FBS) (Bio Whitaker, Belgium), $2 \mathrm{mML}$-glutamine (Bio Whitaker, Belgium), $20 \mathrm{mM}$ Hepes (Bio Whitaker, Belgium), $100 \mathrm{U} / \mathrm{mL}$ penicillin, and $100 \mu \mathrm{g} / \mathrm{mL}$ streptomycin (Bio Whitaker, Belgium). Selection of LUC positive parasites was done by adding geneticinsulphate (Sigma-Aldrich, USA) to the culture media at a final concentration of $5 \mu \mathrm{g} / \mathrm{mL}$. Parasites were maintained in culture, at $26^{\circ} \mathrm{C}$ by subpassage $\left(10^{\circ} \mathrm{C}\right.$ parasites $\left./ \mathrm{mL}\right)$ at every 5 days.

L. infantum axenic amastigotes, stably expressing the LUC gene were derived from promastigotes by culturing them in MAA (Medium for Axenic Amastigotes) culture medium. MAA consisted of a modified medium 199 with Hanks balanced salt solution (Gibco-Invitrogen, Spain) supplemented with $0.5 \%$ soya broth trypto-casein (Bio-Rad, UK), $15 \mathrm{mM}$ D-glucose (Panreac, Spain), $4 \mathrm{mM} \mathrm{NaHCO} 3$ (Sigma-Aldrich, USA). The $\mathrm{pH}$ was adjusted to 5.8, and the media was $0.2 \mu \mathrm{m}$ sterilized by filtration and further supplemented with $0.023 \mathrm{mM}$ bovine hemin (Fluka, USA), $5 \mathrm{mM}$ L-glutamine, and $25 \%$ of heat inactivated FBS. Amastigotes were maintained in culture, at $37^{\circ} \mathrm{C}$ in an atmosphere containing $5 \% \mathrm{CO}_{2}$ by subpassage $\left(10^{5}\right.$ parasites $\left./ \mathrm{mL}\right)$, at every 5 days.

3.3.2. Cell Lines. The human leukaemia monocyte THP1 cell line was cultured as a monolayer at $37^{\circ} \mathrm{C}$ in a humidified atmosphere containing $5 \% \mathrm{CO}_{2}$. Cells were grown in RPMI 1640 medium, supplemented with $10 \%$ heatinactivated FBS, $2 \mathrm{mM}$ L-glutamine, $100 \mathrm{U} / \mathrm{mL}$ penicillin, and $100 \mu \mathrm{g} / \mathrm{mL}$ streptomycin, and were maintained in culture, by subpassage every 3 days.

3.4. Toxicity of Aurones on THP1-Differentiated Macrophages. For macrophage differentiation, human leukaemia monocyte cell line (THP-1 cells) cells were incubated in the presence of $20 \mathrm{ng} / \mathrm{ml}$ phorbol 12-myristate 13-acetate (PMA, Sigma-Aldrich) for $18 \mathrm{~h}$ at $37^{\circ} \mathrm{C}, 5 \% \mathrm{CO}_{2}$, and left another $24 \mathrm{~h}$ with fresh medium containing no PMA to induce maturation. Serial dilutions of each aurone, ranging from 100 to $1.56 \mu \mathrm{M}$ in culture media, were added to the wells, in quadruplicate, and incubated for $72 \mathrm{~h}$ at $37^{\circ} \mathrm{C}, 5 \% \mathrm{CO}_{2}$. Cell viability was assessed by the MTT assay, as described before [35].

The $\mathrm{IC}_{50}$ value, that is, the concentration of the aurone necessary to decrease cell viability to $50 \%$ of the untreated control, was determined by linear regression analysis.

3.5. Growth Inhibition Assays. THP1-differentiated macrophages were infected for a period of $4 \mathrm{~h}$ with stationary phase LUC expressing, L. infantum axenic amastigotes, at a $5: 1$ parasite to cell ratio. After the infection period, cells were washed with culture media to remove noninternalized parasites. Serial dilutions of the aurones, ranging from 50 to $0.78 \mu \mathrm{M}$ in culture media, were added to the wells, in quadruplicate, and incubated for $72 \mathrm{~h}$ at $37^{\circ} \mathrm{C}, 5 \% \mathrm{CO}_{2}$. After the incubation period, the luciferase activity of intracellular amastigotes was determined as described before [36]. The percentage of growth inhibition was calculated as described above.

3.6. Molecular Modeling Calculations. Molecular Modeling calculations were performed using MacroModel module of Schrodinger package, (Schrodinger, LLC, New York, NY, 2011). $E$ and $Z$ isomers for the four selected aurones were initially energetically minimized using Molecular Mechanics with OPLS_2005 force field and $\mathrm{CHCl}_{3}$ as solvent, simulating the environment of the NMR solvent. Minimization was performed with PRCG "Polak-Ribiere Conjugate Gradient" algorithm using 1000 iterations and an energy tolerance of $0.05 \mathrm{kcal} / \mathrm{mol}^{-1} \AA^{-1}$, to reach a local minimum.

\section{Conclusions}

A series of substituted aurones have been synthesized and tested for their antileishmanial activity against the intracellular form of $L$. infantum parasite as well as their cytotoxicity against mammalian cells. The position of the substituents as well as their electronic nature seem to play an important role in the antiparasitic activity. Among the twelve tested compounds, the aurones $4 \mathbf{i}$ and $4 \mathbf{j}$, possessing methoxy groups at positions 4 and 6 of ring A and electron-donating groups on position $2^{\prime}$ of ring $B$ exhibited antiparasitic activity comparable to that of Amphotericin B. The significant antileishmanial activity of aurones $4 \mathbf{i}$ and $\mathbf{4 j}$ is combined with low cytotoxicity, thus rendering these compounds eligible 
for further studies toward the design and synthesis of novel antileishmanial agents possessing this naturally occurring "privileged" scaffold.

\section{Acknowledgments}

The present collaboration was promoted by COST action CM0801 "New drugs for neglected diseases." Sofia Costa Lima thanks Fundação para a Ciência e Tecnologia (FCT) and FSE (III Quadro Comunitário) for the Grant SFRH/BPD/37880/2007. The contribution of Dr. Panagiotis Zoumpoulakis in the molecular modeling calculations is gratefully acknowledged.

\section{References}

[1] http://www.who.int/leishmaniasis/burden/en/.

[2] H. C. Maltezou, "Drug resistance in visceral leishmaniasis," Journal of Biomedicine \& Biotechnology, vol. 2010, Article ID 617521, 2010.

[3] J. Alvar, S. Yactayo, and C. Bern, "Leishmaniasis and poverty," Trends in Parasitology, vol. 22, no. 12, pp. 552-557, 2006.

[4] J. Alvar, P. Aparicio, A. Aseffa et al., "The relationship between leishmaniasis and AIDS: the second 10 years," Clinical Microbiology Reviews, vol. 21, no. 2, pp. 334-359, 2008.

[5] A. Pavli and H. C. Maltezou, "Leishmaniasis, an emerging infection in travelers," International Journal of Infectious Diseases, vol. 14, no. 12, pp. e1032-e1039, 2010.

[6] K. J. Evans and L. Kedzierski, "Development of vaccines against visceral leishmaniasis," Journal of Tropical Medicine, vol. 2012, Article ID 892817, 2012.

[7] S. Sundar, D. K. More, M. K. Singh et al., "Failure of pentavalent antimony in visceral leishmaniasis in India: report from the center of the Indian epidemic," Clinical Infectious Diseases, vol. 31, no. 4, pp. 1104-1107, 2000.

[8] C. Bern, J. Adler-Moore, J. Berenguer et al., "Liposomal amphotericin B for the treatment of visceral leishmaniasis," Clinical Infectious Diseases, vol. 43, no. 7, pp. 917-924, 2006.

[9] L. Ordóñez-Gutiérrez, R. Espada-Fernández, M. A. DeaAyuela, J. J. Torrado, F. Bolás-Fernandez, and J. M. Alunda, "In vitro effect of new formulations of amphotericin B on amastigote and promastigote forms of Leishmania infantum," International Journal of Antimicrobial Agents, vol. 30, no. 4, pp. 325-329, 2007.

[10] S. L. Croft, M. P. Barrett, and J. A. Urbina, "Chemotherapy of trypanosomiases and leishmaniasis," Trends in Parasitology, vol. 21, no. 11, pp. 508-512, 2005.

[11] B. L. Herwaldt, "Miltefosine-the long-awaited therapy for visceral leishmaniasis?" The New England Journal of Medicine, vol. 341, no. 24, pp. 1840-1842, 1999.

[12] T. S. Tiuman, A. O. Santos, T. Ueda-Nakamura, B. P. D. Filho, and C. V. Nakamura, "Recent advances in leishmaniasis treatment," International Journal of Infectious Diseases, vol. 15, no. 8, pp. e525-e532, 2011.

[13] T. Polonio and T. Efferth, "Leishmaniasis: drug resistance and natural products," International Journal of Molecular Medicine, vol. 22, no. 3, pp. 277-286, 2008.

[14] I. Papanastasiou, K. C. Prousis, K. Georgikopoulou et al., "Design and synthesis of new adamantyl-substituted antileishmanial ether phospholipids," Bioorganic and Medicinal Chemistry Letters, vol. 20, no. 18, pp. 5484-5487, 2010.
[15] V. P. Pandey, S. S. Bisht, M. Mishra et al., "Synthesis and molecular docking studies of 1-phenyl-4-glycosyldihydropyridines as potent antileishmanial agents," European Journal of Medicinal Chemistry, vol. 45, no. 6, pp. 2381-2388, 2010.

[16] M. L. Bello, L. D. Chiaradia, L. R. S. Dias et al., "Trimethoxychalcone derivatives inhibit growth of Leishmania braziliensis: synthesis, biological evaluation, molecular modeling and structure-activity relationship (SAR)," Bioorganic and Medicinal Chemistry, vol. 19, no. 16, pp. 5046-5052, 2011.

[17] J. A. Peixoto, M. L. A. E. Silva, A. E. M. Crotti et al., "Antileishmanial activity of the hydroalcoholic extract of miconia langsdorffii, isolated compounds, and semi-synthetic derivatives," Molecules, vol. 16, no. 2, pp. 1825-1833, 2011.

[18] R. Sen and M. Chatterjee, "Plant derived therapeutics for the treatment of Leishmaniasis," Phytomedicine, vol. 18, pp. 10561069, 2011.

[19] M. J. Chan-Bacab and L. M. Peña-Rodríguez, "Plant natural products with leishmanicidal activity," Natural Product Reports, vol. 18, no. 6, pp. 674-688, 2001.

[20] H. Cheng, L. Zhang, Y. Liu et al., "Design, synthesis and discovery of 5-hydroxyaurone derivatives as growth inhibitors against HUVEC and some cancer cell lines," European Journal of Medicinal Chemistry, vol. 45, no. 12, pp. 5950-5957, 2010.

[21] H. M. Sim, C. Y. Lee, P. L. R. Ee, and M. L. Go, "Dimethoxyaurones: potent inhibitors of ABCG2 (breast cancer resistance protein)," European Journal of Pharmaceutical Sciences, vol. 35, no. 4, pp. 293-306, 2008.

[22] H. M. Sim, K. Y. Loh, W. K. Yeo, C. Y. Lee, and M. L. Go, "Aurones as modulators of ABCG2 and ABCB1: synthesis and structure-activity relationships," ChemMedChem, vol. 6, no. 4, pp. 713-724, 2011.

[23] B. P. Bandgar, S. A. Patil, B. L. Korbad, S. C. Biradar, S. N. Nile, and C. N. Khobragade, "Synthesis and biological evaluation of a novel series of 2,2-bisaminomethylated aurone analogues as anti-inflammatory and antimicrobial agents," European Journal of Medicinal Chemistry, vol. 45, no. 7, pp. 3223-3227, 2010.

[24] S. Venkateswarlu, G. K. Panchagnula, A. L. Gottumukkala, and G. V. Subbaraju, "Synthesis, structural revision, and biological activities of $4^{\prime}$-chloroaurone, a metabolite of marine brown alga Spatoglossum variabile," Tetrahedron, vol. 63, no. 29, pp. 6909-6914, 2007.

[25] A. Detsi, M. Majdalani, C. A. Kontogiorgis, D. HadjipavlouLitina, and P. Kefalas, "Natural and synthetic 2'-hydroxychalcones and aurones: synthesis, characterization and evaluation of the antioxidant and soybean lipoxygenase inhibitory activity," Bioorganic and Medicinal Chemistry, vol. 17, no. 23, pp. 8073-8085, 2009.

[26] R. Haudecoeur, A. Ahmed-Belkacem, W. Yi et al., "Discovery of naturally occurring aurones that are potent allosteric inhibitors of hepatitis $\mathrm{C}$ virus RNA-dependent RNA polymerase," Journal of Medicinal Chemistry, vol. 54, no. 15, pp. 5395-5402, 2011.

[27] C. Y. Lee, E. H. Chew, and M. L. Go, "Functionalized aurones as inducers of $\mathrm{NAD}(\mathrm{P}) \mathrm{H}$ :quinone oxidoreductase 1 that activate AhR/XRE and Nrf2/ARE signaling pathways: synthesis, evaluation and SAR," European Journal of Medicinal Chemistry, vol. 45, no. 7, pp. 2957-2971, 2010.

[28] O. Kayser and A. F. Kiderlen, "Leishmanicidal activity of aurones," Tokai Journal of Experimental and Clinical Medicine, vol. 23, no. 6, pp. 423-426, 1998.

[29] O. Kayser, M. Chen, A. Kharazmi, and A. F. Kiderlen, "Aurones interfere with Leishmania major mitochondrial fumarate 
reductase," Zeitschrift fur Naturforschung C, vol. 57, no. 7-8, pp. 717-720, 2002.

[30] Arunima and N. D. Kurur, "Ortho effect in fluorobenzenes: cross-correlated relaxation and quantum chemical studies," Magnetic Resonance in Chemistry, vol. 43, no. 2, pp. 132-138, 2005.

[31] M. Zhang, X.-H. Xu, Y. Cui, L.-G. Xiea, and C.-H. Kong, "Synthesis and herbicidal potentialof substituted aurones," Pest Management Science. In press.

[32] B. Srinivasan, T. E. Johnson, R. Lad, and C. Xing, "Structureactivity relationship studies of chalcone leading to 3-hydroxy$4,3^{\prime}, 4^{\prime}, 5^{\prime}$-tetramethoxychalcone and its analogues as potent nuclear factor $\kappa \mathrm{B}$ inhibitors and their anticancer activities," Journal of Medicinal Chemistry, vol. 52, no. 22, pp. 7228-7235, 2009.

[33] P. Boeck, P. C. Leal, R. A. Yunes et al., "Antifungal activity and studies on mode of action of novel xanthoxyline-derived chalcones," Archiv der Pharmazie, vol. 338, no. 2-3, pp. 87-95, 2005.

[34] H. Sekizaki, "Synthesis of 2-benzylidene-3(2H)-benzofuran3 -ones (aurones) by oxidation of 2 -hydroxychalcones with mercury(II) acetate," Bulletin of the Chemical Society of Japan, vol. 61, pp. 1407-1409, 1988.

[35] T. Mosmann, "Rapid colorimetric assay for cellular growth and survival: application to proliferation and cytotoxicity assays," Journal of Immunological Methods, vol. 65, no. 1-2, pp. 55-63, 1983.

[36] G. Roy, C. Dumas, D. Sereno et al., "Episomal and stable expression of the luciferase reporter gene for quantifying Leishmania spp. infections in macrophages and in animal models," Molecular and Biochemical Parasitology, vol. 110, no. 2, pp. 195-206, 2000. 


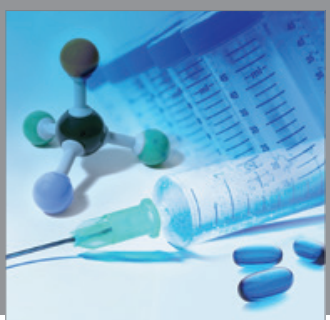

International Journal of

Medicinal Chemistry

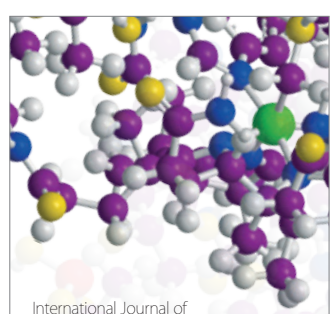

Carbohydrate Chemistry

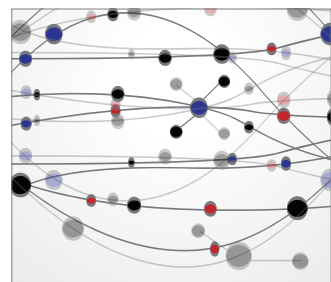

The Scientific World Journal
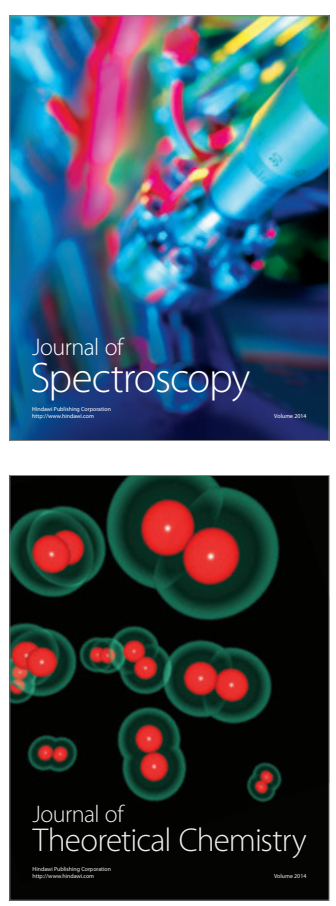
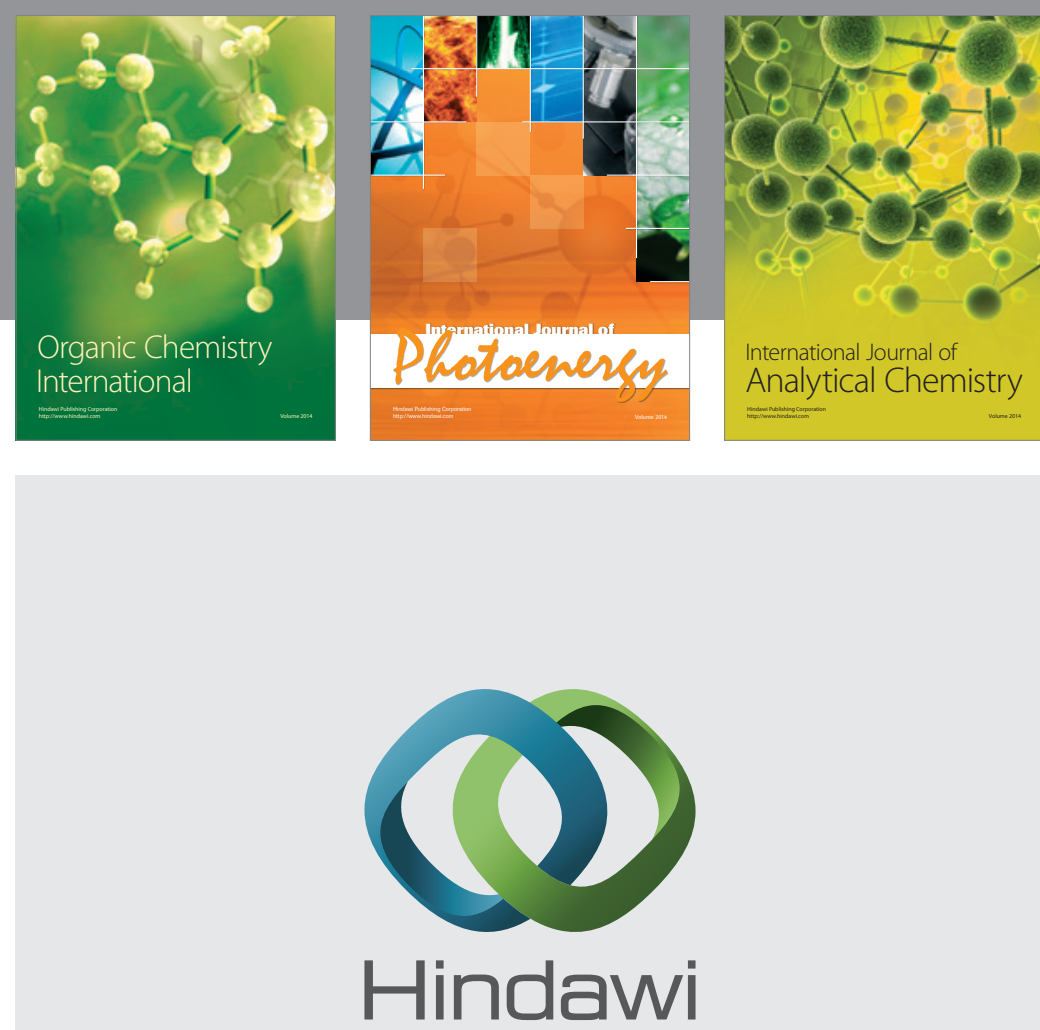

Submit your manuscripts at

http://www.hindawi.com
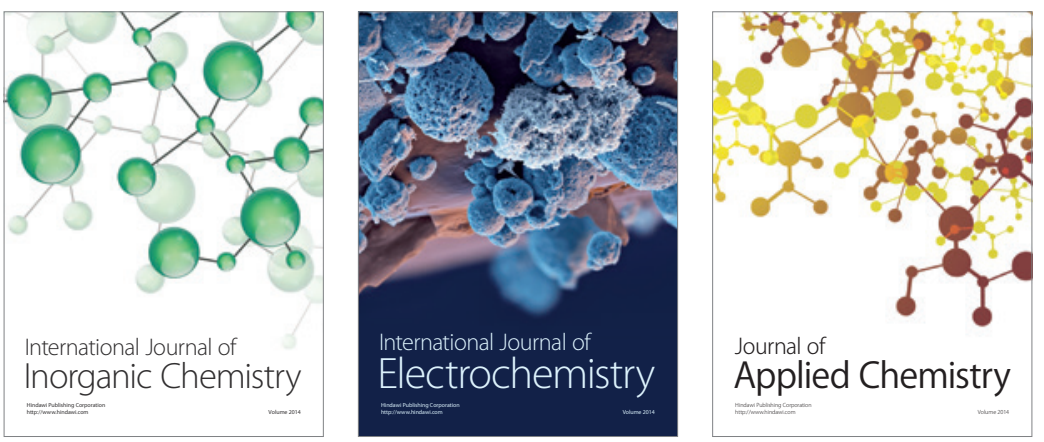

Journal of

Applied Chemistry
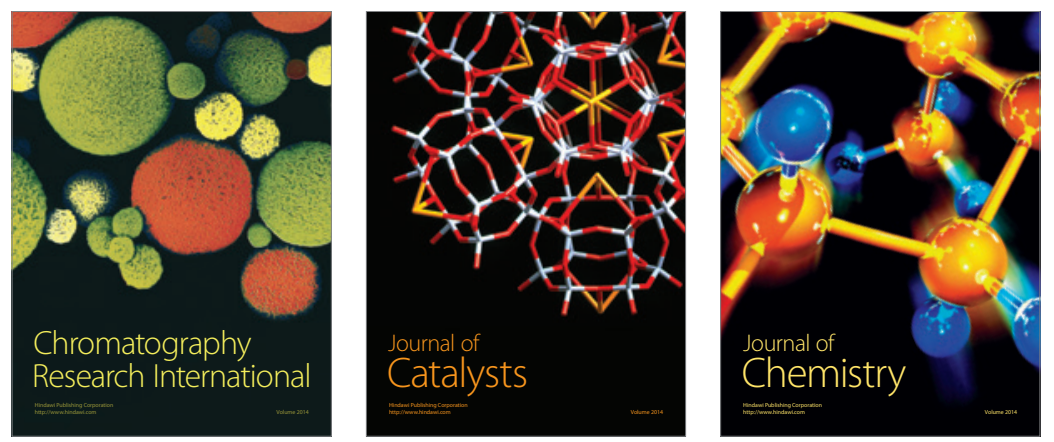
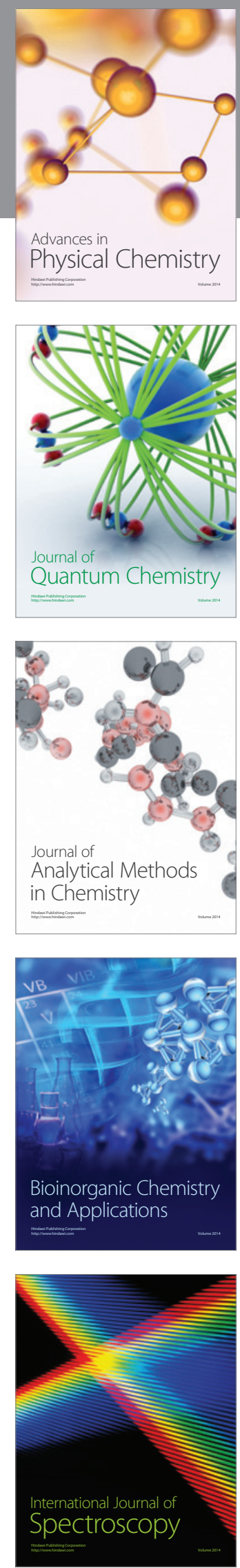